\title{
Marx, Vygotsky and Freire: methodological discussions on the role of language in social transformation
}

\author{
Marx, Vygotsky e Freire: discussões metodológicas sobre o \\ papel da linguagem na transformação social
}

\author{
Peter E Jones ${ }^{1,2}$ \\ Maria Cecilia C Magalhães ${ }^{3,4}$
}

\section{ABSTRACT}

This paper offers a Marxist grounding for a liberatory, criticalcollaboratory dialogic praxis in educational contexts and examines the implications of such praxis for an understanding of the potential role

1. Sheffield Hallam University. Sheffield, South Yorkshire, United Kingdom. http://orcid. org/0000-0002-1225-0192. E-mail: P.E.Jones@shu.ac.uk.

2. Peter E Jones is Reader in Language and Communication within the Department of Humanities at Sheffield Hallam University. His main interests lie in Marxist theory and its relevance for linguistic research, in Vygotsky's cultural-historical psychology, and in integrationism as a philosophy of communication.

3. Pontifícia Universidade Católica de São Paulo (PUC-SP). São Paulo - Brasil. orcid. org/0000-0002-8567-0358. E-mail: cicamaga@gmail.com.

4. Maria Cecília C Magalhães is a full professor at PUC-SP, at the Department of Language Sciences and the Post-Graduate Program of Applied Linguistics and Language Studies. Her main interests are on the theoretical-methodological approach to critical collaborative research organization, within the theoretical frame of the Socio-Historical-Cultural Activity. 
of the school as a site of critical thinking. Aligning with Stetsenko's 'Transformative-Activist Stance', the discussion centres on clarifying the methodological rationale for approaching language as a means of cultural action and social transformation based on Marx's materialist conception of history and the educationally based dialogical approaches of Vygotsky and Freire.

Keywords: critical-collaborative language; transformative action; dialogic praxis; materialist conception of history.

\section{RESUMO}

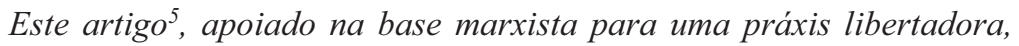
dialógica e crítico-colaborativa em contextos educacionais, examina as implicações dessa práxis para a compreensão do papel potencial da escola como lócus de pensamento crítico. Alinhando-se à "Posição Transformadora-Ativista" de Stetsenko, a discussão concentra-se em clarificar a abordagem metodológica para enfocar a linguagem como um meio de ação cultural e transformação social, com base na concepção marxista materialista de história e nas abordagens dialógicas educacionais de Vygotsky e Freire.

Palavras-chaves: linguagem critico-colaborativa; ação transformadora; práxis dialógica; concepção materialista da história.

\section{Introduction}

True dialogue cannot exist unless it involves critical thinking - thinking which discerns an indivisible solidarity between the world and men admitting of no dichotomy between them - thinking which perceives reality as process and transformation, rather than as a static entity - thinking which does not separate itself from action, but constantly immerses itself in temporality without fear of the risks involved' (Freire, 1972: 64-65).

5. This paper resulted from discussions during the Minicourse "Vygotsky and the Marxist tradition: achievements, problems and perspectives" developed by Peter Jones (2019) as an Invited Researcher at Pontifícia Universidade Católica de São Paulo [Pontifical Catholic University of São Paulo], Brazil (PUC-SP). We thank the PIPEq- Invited Research support from PUC-SP that allowed the development of this paper and the research support from 
Our basic aim here is to offer a Marxist grounding for a particular dialogical praxis within the liberatory, critical-collaboratory tradition of 'problem-posing education' (Freire, 1972) and consider its implications in realizing the potential role of the school as a site of 'cultural synthesis' (Freire, 1972) within a transforming social totality. The paper draws on fundamental principles of Marx's 'materialist conception of history' concretized through the educationally-based dialogical approaches of Vygotsky and Freire and the recent attempt at a new synthesis of such intellectual currents in Anna Stetsenko's 'Transformative-Activist Stance' (Stetsenko, 2017).

The radical politico-economic transformation of society involves organization of progressive social actors on a mass scale. Such organization requires its own communicational practices - 'cultural action' (Freire, 1972: 147) - as a break with the alienating practices of the exploitative past and present. In that light, here we examine the potential of dialogical action for opening to conscious critique and transforming the very modes of communication and organization through which institutional schooling ('banking education', Freire, 1970 ) is usually constituted. Given the contradictory character of all social institutions within a conflictual social order built on class struggle, we argue that the socio-communicative regime of the school, ostensibly imposed to fragment and alienate the oppressed, in fact also offers a transformable platform for critical contestation and organization-for-social-revolution. We focus particularly on dialogue as the core praxis for critical collaboration between teachers and students in working out how to construct a unity of social forces 'directed towards humanization' (Freire, 1972: 58).

\section{Starting from Marx}

It is often taken for granted in discussions of cultural-historical theory that the fundamental principles of this tradition are traceable to Marx's theoretical and scientific legacy. Did not Lev Vygotsky, after all, aspire to create a 'Marxist psychology', informed by the method of Marx's Capital (Vygotsky, 1987)? The issue is by no means straightforward, as readers will know, since scholars differ on what aspects of Vygotsky's approach could be said to be Marxist in origin 
or inspiration (cf) Jones, 2018a, 2019; Ratner,2017; Stetsenko, 2017). The sustained line of work by Peter Keiler, uncovering and elucidating the specifically Feuerbachian source and inspiration for key principles of cultural-historical psychology (Keiler, 2017) further complicates the picture.

In this paper we will take it that the simple answer to our question lies not so much in a historically oriented reflection on texts, written, after all, for different audiences and in different context. Rather, the answer is to be found, ultimately, in the endeavour to move forward to forge the intellectual tools and collaborative social practices that are vital - indeed, necessary - to overcome the daunting problems now before us as a consequence of the persistent global domination of an exploitative economic and political system which has brought humanity to the brink of disaster. It is on this future-oriented ground, in the spirit of Stetsenko (2017), that we position our own appropriation and transformation of the ideas of both Vygotsky and Freire within a Marxist-based methodology.

After all, the fundamental problem at stake in our thinking and action is how we understand what is going on in society and how we work out, in our practical interventions, what to do about it. More specifically, we are concerned with how we approach the task of understanding the specific social role and social function of educational institutions and educational practices within society today, what we might do to transform them and ourselves in the process, and how such transformation may contribute to the progressive transformation of social relations more generally. It is from that perspective that we seek to understand a) the import and implications of the method and ideas of Marx for an understanding of education within capitalist society, and b) how the contributions of Paulo Freire and Lev Vygotsky may help us to develop a more concrete vision for the potential role of dialogical practices in education in relation to the urgent and acute problems of the world today.

Marx's analysis of capitalism in Capital begins with the commodity, a historically specific form of capture (by the capitalist "valorization process') of the labour process, the latter a necessary condition of all forms of human society. But Marx's analysis does not end there; it is 
simply the starting point for a systematic analytical re-creation of all the social relations, functions and practices peculiar to a society based on the exploitation of human activity by capital. His initial analysis takes the process of commodity production in isolation from all the other processes and forms of activity, including education, law, politics and so on, in which it is empirically embedded. Such isolation, or abstraction, is viewed by Marx as essential to constructing a fully concrete picture of capitalist society, on the assumption that, in its ascendency, the capitalist mode of production strives to reshape and redesign all domains of social life to serve the interests of capital and to quell or suborn all forms of resistance to that dominance.

At the same time, and in contrary motion, the agents of the labour process struggle to protect themselves from exploitation, to get a bigger share of the product of their own labour in the shape of higher wages, housing, education, health care, leisure time and so on. They also strive to develop their own forms of organization - historically, trade unions and political parties - to enhance and amplify through the collectivity their powers of resistance and to articulate an alternative vision of society without exploitation. And so, If the exploitation of living labour is the basic economic condition and ground of capitalist production, then this ground is continually contested, a contest which plays out everywhere in society, through all its institutions, since all spheres of life and work are interconnected on this ground. Accordingly, Marx's method does not involve reducing each and every sphere of production or working practice in society to the same abstract model of commodity or capital production but in tracing how these spheres and practices grow up as inter-dependent and inter-related processes on the basis of the struggles to impose, and to resist, capitalist exploitation of labour (Jones, 2009). Marxist analysis comes into its own, therefore, precisely when we need to see the bigger picture into which our own professional practices and aspirations fit (Jones, 2011a). The apparently very 'concrete', local work activity of any particular professional sphere or branch of the social division of labour is, in fact, an abstract and, consequently unhelpful, starting point for trying to find a clear understanding of the deeper societal processes and conflicts which shape, often drastically and without compromise, the lives and livelihoods of hundreds of millions of people independently of, or despite, their personal intentions, goals and aspirations. 
For that same reason, Marx himself was an opponent of narrow and doctrinaire 'economistic' thinking and the staunchest supporter of any and all attempts to improve working conditions and practices as well as conditions of life generally within the framework of existing exploitative relations of production. Any humane measure which would encroach on and limit the demands and dominance of capital, such as compulsory education or legal or constitutional enshrinements of basic rights, was taken as a positive step towards the affirmation and assertion of human values, of universal human potential. And indeed, because of the all-sided interconnections and interactions between forms of social activity, any struggle on any front, however small scale, therefore offered scope for a contest of political aims and priorities. Similarly, any achievements made in struggle, whether material or ideological, created staging posts for wider and deeper social change and transformation. Thus, from Marx's perspective the struggle against exploitation is one to be carried out on all fronts and may begin anywhere, since all challenges to the status quo can become, in Harvey's (2011: 231) words, 'the co-revolutionary points around which social action could converge and rotate'.

What, then, is specific to education under capitalist conditions? What is the concrete role played by educational institutions and practices in societies built up around the exploitation of labour? And, most importantly, what opportunities exist for teachers and students to transform educational spaces into catalysts for social change?

\section{Education in Marxist perspective}

As noted in Jones (2011b), Marx did not see compulsory schooling as a capitalist conspiracy to ideologically enslave the working class but as a necessary and progressive reform which protected the children of working class families from exploitation in factories and mines, sparing their lives and health in the process. This legal move also protected them at the same time from their own families who, as a result of poverty and exhaustion, were obliged to force their own children into abusive and exploitative work. For Marx, then, socialized schooling represented a shield, a humanitarian measure, a mitigation of the exploitative forces 
at work in society and, by that same measure, both a cultural as well as an economic inroad into capitalist hegemony.

On the other hand, of course, the separation of school systems from the world of work turns 'education' into a very peculiar, problematic and deeply conflicted business, as cultural-historical theory has been careful to point out (see the discussion in Jones, 2011b). But by the same token, the legally enforced separation of (child) labour from both capital and the pressures of domestic poverty creates a space of possibilities within the classroom for intellectual and practical action in relation to social relations inside and outside the school. Thus, concrete school systems are always the outcome of a complex balance of competing and conflicting forces within society overall. Exactly what goes on at school is from the very beginning also a contest or, rather, is part of the wider contest between labour and capital.

Any educational system or institution, therefore, represents an unstable confluence of various social functions representing conflicting social interests. That also means that the role of the school, or of the individual teacher, with respect to these wider social struggles, is neither pre-determined nor set in stone: the social role of the school, indeed, the pedagogical relationship itself, is up for grabs. To affirm, for instance, that education is a right for all, that it should really educate, motivate and inspire, that it should help protect us from exploitation and poverty, that it should not reproduce but counter social inequality - all of this is also a call to arms: it says what education should be, what it can be, and leads us to find ways and means to make it so. Just as, for example, to say that good clean water should be accessible and free to everyone is at the same time a challenge to the private utilities (and their political backers) who profit from natural resources while leaving billions of people worldwide without proper drinking water.

This means that teachers have the chance, when circumstances are propitious, to make a real difference to both their students and their communities. Schools can provide safe opportunities to learn outside of the home, outside of the workplace, off the streets; they can help to raise awareness in children and their families of basic health issues; they can become catalysts of community self-education; they can help communities to organize, to help them find their voice and use it; they can 
help communities gain confidence and strengthen their sense of identity; they can help to create a vision of an alternative future for the working people and poorest sections of society and challenge the inequalities of wealth that determine life chances and, indeed, life expectancy; and they can help to create a new vision of what real learning is and how it should be developed and rewarded. If opportunities of this kind can be made or seized, then schooling becomes a powerful transformative practice. In these circumstances teachers can become role models for empowerment and social conscience, just as enlightened employers, in providing conditions for labour to take place with dignity and in spaces where personal learning and growth can take place, can also play a part in advancing the cause of progressive social change.

While such general reflections, informed by Marx's thinking, may be a useful starting point for contextualizing the problem of education, and the school, in wider social processes, the world today is faced with challenges and problems that were quite unknown in Marx's day and which require new forms of analysis and, more importantly, new forms of practice. More particularly, the global climate emergency challenges us all to re-appraise our traditional forms of resistance to capitalist domination in general and our view of the school and its social role more especially. Indeed, such a re-appraisal - in theory and practice has already motivated the new generations of school children across the world to take their own independent protest and strike action against existing political, economic, cultural and educational institutions which have proved incapable of rising to the urgent tasks of global governance that the climate emergency requires.

For schools in particular, the contradictory character of their social 'mission' has been stretched to breaking point and the ideology of schooling as a preparation for a prosperous future life exposed as a lie: what future life could the school prepare us for if the world itself is becoming uninhabitable? And if the school is not doing its utmost to educate to this emergency agenda and to promote such awareness throughout society, then the school itself becomes complicit in the destruction of the earth.

All of this, then, puts the role of teachers in uncharted territory and, more acutely than ever before, forces us as educators to confront 
the challenge of how to help, rather than hinder, children's own selfactualization for their future. Rather than preparing them for what we may have believed was a bright(er) future in a world of enhanced opportunity, we find that the present world is now literally disappearing and the vision of that better world a grotesque fantasy which distorts, if not poisons, our whole authority as educators and guides to future life. After all, what right do we have to insist on students' compliance with the game of institutional education, their attendance at school, their conformity to school discipline and attention to the curriculum if all this is part of the problem and not part of the solution? What can we do to help children become leaders in this struggle for their future - humanity's future - and to develop the organizational means to win it?

Furthermore, as becomes increasingly clear, the fight for adequate climate practice and policy is at the same time the fight for social justice and equality throughout the world. It has never been truer to say that the fight for an end to capitalist exploitation and the fight to rescue humanity completely coincide. As Magalhães and Fidalgo (2019: 4) put it in their review of critical research methodologies for teacher education in applied linguistics:

Critical Research must therefore be an attempt to confront unfairness; an effort to implement dialectical relations, allowing for world contradictions to come forth and domineering cultural features to be challenged. As part of the school, critical theory must be a process of hope where joint work between different agents (researcher, teacher, students, other staff members, parents and the surrounding communities) takes place, ultimately transforming the school, the society and participants themselves as part of the process.

\section{Language and revolution - from Marx to Vygotsky and Freire}

How, then, can we develop a more concrete appreciation of the role of language as a means of cultural action and social transformation from a Marxist perspective? After all, the (vulgar) Marxist may object that since the pedagogical process is one involving language - mere talk about things - rather than 'real' material-practical activity, then we are mistaken in attributing a radical, transformative role to the teacher-educator. To this, we can only respond with Marx's own views 
on language as a social activity and social force. For Marx and Engels, language was both 'practical consciousness that exists' for others 'and for that reason alone it really exists for me personally as well' and a principal vehicle for the 'ideological forms' in which people 'fight out' the 'contradictions of material life' (Marx and Engels in Jones, 2018a: 2).

Progressive social movements, consequently, 'are at once struggles for foundational economic, political and social change and at the same time necessarily struggles over language, about language, in language and for language which enables and promotes the consciousness and organization upon which such transformation depends' (Jones, 2018a: 3; see also Collins, 1999).

One might therefore ask:

How else could theory 'get a hold of' working people and 'become a material force' for revolutionary transformation other than by this prodigious, creative linguistic and communicational labour through which collective agency becomes consciously organized and mobilised in struggle? (Jones, 2018a: 7)

\section{Indeed, as Emmanuel Schegloff noted:}

As it happens, this activity - conversation and its transformations into other forms of talk-in-interaction - is the vehicle through which a very great portion of the ordinary business of all the major social institutions (and the minor ones as well) gets addressed and accomplished. It is evident that much even most - of the work of such institutions as the economy (in its several institutional contexts), the polity (in its several contexts), the institutions for population replacement (courtship, marriage, socialization, and education), the law, religion, social control, culture, and so forth, is accomplished in episodes of talk-in-interaction (Schegloff, 1992: 1340).

\section{More specifically, Schegloff goes on:}

On the one hand, much of the grasp of the world that informs the sentience and conduct of members of a society is, or can be, managed (crystallized, assessed, challenged, clarified, revised, confirmed, shared, reinforced, etc.) through talk, including objects of understanding that are not themselves talk. Any reference to an object, person, action, dream, fantasy, that is, 
anything real, or unreal but mentionable, and indeed anything understood to be presumed or presupposed by what is said or conveyed, can be made the object of talk - not necessarily at topic, but what the talk is understood to bear on (1992: 1340).

Nevertheless, some theoretical clarification is undoubtedly necessary if we wish to reconcile the insights of such talk-centred approaches with Marx's materialist conception of history and the goal of general societal transformation. At stake in particular is the relationship between innovations in practice within specific episodes and contexts of talk (dialogue) and effective interventions in the broader, often hidden or unexamined, networks of practical and communicational processes through which the conflictual movement of the social whole is constantly generated and transformed. As Harris (1996: 17) puts it: "no form of communication in which human beings engage can be carried on except as part of some broader pattern of activities, to which it contributes, but which, in turn, support its mode of operation'. And therefore, more broadly:

Any initial academic strategy which, for theoretical purposes, treats communication processes or communication systems as segregated, self-contained structures, and assumes that each must be analysed exclusively "in its own terms", without any reference whatsoever to neighbouring processes or syste$\mathrm{ms}$, is not merely methodologically flawed but promotes an utterly misleading view of the matters it purports to deal with (Harris, 1996: 17-18).

More pointedly still, as Jones (2018b: 131) notes: "we inhabit a communicational universe organized not by dialogic principles but by the active construction of communication processes in which and around which dialogical interaction itself (if and when it occurs) must be anchored.'

From that point of view, the dialogical practices within the school must be seen in their future-oriented, synergistic contribution to the transformability of that dynamic and constantly emergent network (a 'creative chain', Liberali, 2011; Magalhães, 2016) of interconnected and inter-constituting communication processes of which 'social reality' actually consists Furthermore, taking a Marxist view on this communicationally constituted 'reality' also fundamentally means 
taking a view on the precise kinds of connections - or communicational presuppositions - which are distinctive to capitalist exploitation:

since all activities of whatever kind in capitalist societies are all connected, however indirectly, they cannot cut loose (except in the imagination) from the one process they all presupppose - the exploitation of one class by another in the production of surplus value. In this way, the class struggle at the heart of the capitalist production process 'communicates itself' through the whole of society: class exploitation is communicationally organized (Jones, 2018a: 10).

The insights of Vygotsky and Freire for an understanding of the role of language praxis in the struggle to transform society

Among Vygotsky's many insights into the educational process, in the context of the child's social development more generally, there are several which are particularly relevant here. Firstly, far from a transmission-based model of educational practice, Vygotsky saw the teaching-learning process as an interaction between more expert adult and child: a collaborative, dialogic process in which the freedom of the child to question, to challenge to reflect on and re-imagine the challenging 'content' of the educational material, in dialogue with the teacher and peers, was indeed the foundation of the whole developmental process. But Vygotsky went further, showing how the very social environment in which the child acts could not be understood - and certainly not re-made - independently of the child's active relationship to his or her manner of engagement with and, therefore, transformation of, this lived 'reality'.

This environment, as Vygotsky (1998:198) put it, should not be viewed 'as something outside with respect to the child, as a circumstance of development, as an aggregate of objective conditions existing without reference to the child and affecting him (sic) by the very fact of their existence.'

Similarly, Vygotsky argued that it was necessary to 'approach environment not with an absolute but a relative yardstick': 'environment should not be regarded as a condition of development which purely objectively determines the development of a child by virtue of the fact that it contains certain qualities or features, but one should always 
approach environment from the point of view of the relationship which exists between the child and its (sic) environment at a given stage of his development' (Vygotsky, [1934]1994: 338).

The environment, then, is not an objectively given thing or condition but a continually renewed and dynamic product of the engagement of the child with the 'reality' to be transformed. The 'social situation of development' (Vygotsky, [1932-34]1998) was precisely then not an objective set of factors or circumstances existing independently of the child but a relationship to the world refracted through the child's vital experience (perezhivanie), the consciously apprehended feeling of life being lived.

Secondly, Vygotsky's late work, despite all the problems and controversies in its understanding and interpretation, is particularly significant for reflecting on the social processes of learning and development and the key role of language and linguistic meaning (and sense) within these processes.

From 1932 onwards, we see a whole series of self-critical reconsiderations and re-evaluations of Vygotsky's work, in effect calling everything into question. In particular the 'causal-mechanical' semiology (Jones, 2019) of his 'instrumental method'/'dual stimulation' phase is radically modified in favour of an emphasis on the meaning of the 'sign operation' for the acting subject, as opposed to any putative causal or impelling power.

Now, the meaning or 'sense' of words (and possibly all communicational phenomena) in relation to the individual subject becomes the primary factor in an understanding of thinking, purposeful action ('free action') and the development of speech itself. Key principles or assumptions of earlier work, in particular the speech internalization process and even the representationalist 'genetic ladder' of conceptual development are challenged in favour of a purely situational-contextual account of word meaning within a purposeful field of sense-saturated action (Zavershneva, 2014). Furthermore, a new unit of psychological understanding is advanced in the form of perezhivanie (Vygotsky, [1934]1994) which carries an intimation of a novel model of semiology in which meaning lies not in some 'auxiliary sign' (a word etc) as mediator of mental processes but in the very 
relationship between the acting subject and the people and things with whom the subject engages.

With these innovations and departures from previous theoretical principles, Vygotsky's thinking arrives at a very different, more productive starting point for a new direction in research and, surely, one which is more in keeping with the spirit of Marx: a concrete focus on the actual lived experience of the social individual and on the developing semiological powers unique to that individual as a function of his/her active life in the community/collective.

Thirdly, for Vygotsky, the role of language was crucial to this developmental process as a dialogic interaction-in-cooperation in which a 'zone of proximal development' (ZPD) could be established:

\begin{abstract}
A closer source of the development of internal individual properties of the child's personality is cooperation (this word understood in its broadest sense) with other people. Thus, by applying the principle of cooperation for establishing the zone of proximal development, we make it possible to study directly what determines most precisely the mental maturation that must be realized in the proximal and subsequent periods of his stage of development (Vygotsky, 1998: 203).
\end{abstract}

For Freire, too, education must be a process of dialogue, but it is one in which all parties - teachers and students - are equally engaged and equally transformed in contributing to it. As with Vygotsky, this is not a transmission process but a process of mutual and collaborative creative questioning and discovery - pushing the barriers and transcending them. The time is up for 'banking education' (Freire, 1972: 52) 'as the exercise of domination stimulating the credulity of students, with the ideological intent (often not perceived by educators) of indoctrinating them to adapt to the world of oppression'. As Freire put it (1972: 53): 'Liberating education consists in acts of cognition, not transferrals of information'. What he referred to as 'problem-posing education' therefore 'demands a resolution of the teacher-student contradiction. Dialogical relations - indispensable to the capacity of cognitive actors to cooperate in perceiving the same cognizable object - are otherwise impossible'. 
Indeed, as he went on:

problem-posing education, breaking the vertical patterns characteristic of banking education, can fulfill its function of being the practice of freedom only if it can overcome the above contradiction. Through dialogue, the teacher-of-the-students and the students-of-the-teacher cease to exist and a new term emerges - teacher-student with students-teachers... They become jointly responsible for a process in which all grow. In this process, arguments based on "authority" are no longer valid; in order to function, authority must be on the side of freedom, not against it. Here no-one teaches another, nor is anyone self-taught. Men (sic) teach each other, mediated by the world, by the cognizable objects which in banking education are "owned" by the teacher.

The fundamental significance of the dialogical, problem-posing approach is the simultaneous breaking down of the social relations and vertical power differential in the traditional teacher-student roles and the transcendence of the cognitive fixity and stability of the object to be cognized: 'The students - no longer docile listeners - are now critical co-investigators in dialogue with the teacher' (1972: 54). For Freire:

In problem-posing education, men (sic) develop their power to perceive critically the way they exist in the world with which and in which they find themselves; they come to see the world not as a static reality, but as a reality in process, in transformation (1972: 56).

Such thinking has been amplified and extended most recently in the work of Anna Stetsenko who calls for 'an elaboration of Marxist and Freirean approaches that would not cancel their core premise of a desired directionality of knowing and development yet guard against these notions morphing into a regime of truth that leads into indoctrination and passive transmission of ideology' (2017: 66).

In her 'Transformative-Activist Stance', Stetsenko insists on the future-oriented or future-creating activity of human beings as the fundamental reality of their social existence:

people can be said to realize their development in the agentive enactment of changes that bring the world, and simultaneously their own lives, including their selves and minds, into reality (2017: 31). 
There is a tension, however, between Vygotsky's conception of the ZPD and the vision of cooperation/collaboration which Freire himself advanced, a tension which the dialogical perspective of Critical Collaboration (Magalhães, 2016) attempts to resolve. Thus, for Vygotsky, the ZPD was a site, or source of the mental development of the child, through cooperation with more capable others. For Freire, on the other hand:

Education must begin with the solution of the teacher-student contradiction by reconciling the poles of the contradiction so that both are simultaneously teachers and students (1972: 46).

Thus, teachers-students and students-teachers (1972: 53) are fully equal partners and participants in the dialogic social process, jointly pushing the horizon of the known into the uncharted waters of 'untested feasibility' (Freire, 1972: 85) Such dialogic action cannot be limited to the (re)production of what any of the partners already know, or can do, but is a genuine becoming - the dawning of an emergent social reality through "'testing action" which reveals its hitherto unperceived viability' (1972: 85). 'Problem-posing education', therefore, 'is revolutionary futurity', 'prophetic (and, as such, hopeful)' (Freire, 1972: 57).

In that light, as Magalhães (2016) has argued, Vygotsky's ZPD must be re-envisioned as the creation of 'a mutual Zone of Proximal Development', that is:

In this context, collaborating means creating trusting and respectful relations in which each participant intentionally acts to mutually and inter-dependently listen to the other and ask problematic questions in order to: comprehend the other's senses, share reasoning, be willing to expand others' and their own understandings, raise doubts, pose challenges and make suggestions, ask for clarification, disagree, review or complement ideas previously explained, describe experiences as a means to relate to others (2016: 42-43).

\section{Dialogue as critical cultural action: the critical-collaborative approach in Applied Linguistics}

According to Magalhães and Fidalgo (2007: 329), in an intervention research developed within a Critical Paradigm, the primary role of 
applied linguists, as researchers and teacher educators, is to work with

language-bound issues as means for organizing the type of thought (...) defined in critical reflective terms, i.e., as a type of thought that might allow individuals - actual agents of their own thoughts [or reasoning processes] - to probe into their routine practices. The focus is on the deconstructionneoconstruction of theoretical-methodological choices that organize educational contexts by looking into the interests they serve, so as to allow for new reasoning and acting, leading to social, political and educational transformations, as pointed out by Vygotsky (1921-23: 463-464).

Magalhães and Fidalgo (2019) argue for a theoretical-methodological approach (Collaborative Critical Research (PCCol)) able to create critical contexts in which participants can act collaboratively, based on a dialogical theory of action "in order to transform the world' (Freire, 1972: 135). For this to be possible, they find support in cultural artefacts that are socio-historically constructed, as well as in experiences organized with the objective of transforming the social environment, its culture and prospective development. Organizing contexts for linguistic communication in which participants, in school environments, can engage in understanding and transforming the world collectively requires one's actions to be focused on contradictions and conflict between the ideas and points of view being discussed. In particular, it is a matter of understanding the intricate organization of argumentative speech that constructs a new shared meaning rather than merely persuades of an existing point of view. This is not an easy task, however, since it involves both an argument-oriented organization of linguistic contributions and collaborative actions. Thus, collaborative relations are an indispensable condition for the negotiation with the other, which presupposes participants' intentional involvement and the development of mutual trust (Magalhães \& Fidalgo, 2007; Ninin, 2006). At the same time, argumentation is necessary for the creation of collaborative relationships and both are responsible for new ways to understand our own and others' ways to think and act in the world: argumentation by itself would seem like an authoritarian imposition if used without collaboration, which would create a difficult negotiation. 


\section{Conclusion}

As stated in the Introduction, our aim in this paper is to offer a Marxist grounding for a liberatory, critical-collaboratory dialogic praxis within a transforming social totality and to examine the implications of this for an understanding of the potential role of the school as a site of 'cultural synthesis' (Freire, 1972). We have therefore attempted to combine fundamental principles of Marx's 'materialist conception of history' with the educationally-based dialogical approaches of Vygotsky and Freire in the light of Anna Stetsenko's 'Transformative-Activist Stance.'

In this theoretical-methodological frame, the role of teachers is to work collaboratively with students to create spaces organized through dialogical action for the posing of problems that they themselves see as central to their own existence, and to build new ways to act on these problems to transform society. In this way, a communicational process is created which allows the participants to critically identify, confront and develop vital themes and topics and ways in which schools, connecting productively with their communities, can find ways to address them. In that creative dialogic action, teachers-students/students-teachers are able to problematize the nature of school knowledge itself as well as the relationship between teachers and students, the relationship between the school and the surrounding 'environment' and to discover new and untested ways to make the pursuit of knowledge a collaboratively organized project for wider social 'conscientization'.

In Freire's words, creating a "true dialogue cannot exist unless it involves critical thinking (...), a kind of thinking which perceives reality as process and transformation, rather than as a static entity - thinking which does not separate itself from action, but constantly immerses itself in temporality without fear of the risks involved" (Freire, 1972: 64-65). As already discussed by Freire (1972: 136), 'Dialogue, as essential communication, must underlie any cooperation'.

We have also noted that Vygotsky's late work brings starting points for a new understanding of collaborative research, focusing on the actual lived experience of the social individual and on the developing semiological powers unique to that individual within his/her active 
life in the community/collective. We hope that these thoughts may be useful in concretizing the principles set out by Marx and Engels in relation to the organizing of dialogical action among subjects through collaborative (cooperative) communication in schools.

\section{References}

COLLINS, C. 1999. Language, Ideology and Social Consciousness: Developing a Sociohistorical Approach. Aldershot: Ashgate.

FREIRE, P. [1970]1972. Pedagogy of the Oppressed. London: Penguin Books.

HARRIS, R. 1996. Signs, Language and Communication. London: Routledge.

HARVEY, D. 2011. The Enigma of Capital and the Crises of Capitalism. London: Profile Books.

JONES, P. E. 2019. Vygotsky and Marxism: re-setting the relationship. In: YASNITSKY, A. (Ed.). Questioning Vygotsky's Legacy. Scientific Psychology or Heroic Cult. London: Routledge. p. 22-42.

JONES, P. E. 2018a. Karl Marx and the language sciences - critical encounters: introduction to the special issue. Language Sciences 70: $1-15$.

JONES, P. E. 2018b. Integrationist reflections on the place of dialogue in our communicational universe: Laying the ghost of segregationism? Language and Dialogue 8 (1): 118-138.

JONES, P. E. 2011a. Activity, Activity Theory and the Marxian Legacy. In: JONES, P. (Ed). Marxism and Education: Renewing the Dialogue. Pedagogy and Culture. New York: Palgrave/Macmillan. p. 193214.

JONES, P. E. 2011b. The Living and the Dead in Education. Commentary on Julian Williams. Mind, Culture, and Activity, 18 (4): 365-373.

JONES, P. E. 2009. Breaking away from Capital? Theorising activity in the shadow of Marx. Outlines: Critical Practice 1: 45-58.

KEILER, P. 2017. "What Is Absolutely Impossible for One Person, Is Possible for Two" - A Historical-Methodological Study Concerning Feuerbachian Elements in the Later Works of L.S. Vygotsky // История российской психологии в лицах: Дайджест. 2017. № 3. C. 179-211. Available in http://journals.hist-psy.ru/index.php/HPRPD/ article/view/328. Accessed on March 1, 2020.

LIBERALI, F. 2011. Cadeia criativa: uma possibilidade para a formação crítica na perspectiva da teoria da atividade sócio-histórico-cultural. 
[Creative chain: a possibility for critical education in the perspective of the socio-cultural-historical activity theory]. In: MAGALHÃES, M. C. C.; FIDALGO, S. S. (Eds.). Questões de método e de linguagem na formação docente [Issues of method and language in teacher education] (pp.41-64) São Paulo, SP: Mercado de Letras.

MAGALHÃES, M. C. C. 2016. Intervention Research in a Public Elementary School: A Critical-Collaborative Teacher Education Project on Reading and Writing. Outlines - Critical Practice Studies 17 (1): 39-61.

MAGAlHÃES, M. C. C. \& FIDALGO, S. S. 2007. The role of methodological choices in investigations conducted in school contexts: Critical research on collaboration in continuing teacher education. In: ALANEN, R.; POYHONEN, S. (Eds.). Language in action: Vygotsky and Leontiev legacy today (pp. 329-352). Newcastle: Cambridge Scholars Publishing.

MAGALHÃES, M. C. C. \& FIDALGO, S. S. 2019. Reviewing Critical Research Methodologies for Teacher Education in Applied Linguistics [Revisando Metodologias Críticas de Pesquisa para formação de professores em Linguistica Aplicada. D.E.L.T.A., 35-3, 2019 (1-19): e2019350301.

NININ, O. 2006. Pesquisa Colaborativa: Das práticas de pesquisa à ressignificação das práticas dos pesquisadores. Tese de Doutorado defendida na PUC-SP-LAEL [Doctoral thesis defense at PUC-SPLAEL].

RATNER, C. 2017. Marxist psychology, Vygotsky's cultural psychology, and psychoanalysis: the double helix of science and politics. In: RATNER, C.; SILVA, D. N. H. (Eds.). Vygotsky and Marx. Toward a Marxist Psychology. London: Routledge.

SCHEGLOFF, E. A. 1992. Repair after next turn: The last structurally provided defense of intersubjectivity in conversation. American Journal of Sociology, Vol. 97, No. 5: 295-1345.

STETSENKO, A. 2017. The Transformative Mind. Expanding Vygotsky's Approach to Development and Education. Cambridge: CUP.

VYGOTSKY, L. S. 1921-23/1997. Educational psychology (Transl. R. R. Silverman). London \& New York: Taylor \& Francis.

VYGOTSKY, L. S. 1930-1934/1987. Problems of general psychology. In: Rieber, R. (Ed.). The Collected Works of L.S. Vygotsky. Vol. 1 (pp.43-51). New York: Plenum.

VYGOTSKY, L. S. 1994. The problem of the environment. In: VEER, R. van der; VALSINER, J. (Eds.). The Vygotsky Reader. Oxford: Blackwell. p. 338-354. 
VYGOTSKY, L. S. 1998. The Problem of Age. The Collected Works of L $S$ Vygotsky Volume 5. New York: Plenum. p. 187-205.

ZAVERSHNEVA, E. 2014. The problem of consciousness in Vygotsky's cultural-historical psychology. In: YASNITSKY, A.; VEER, R. van der; FERRARI, M. (Eds.). The Cambridge Handbook of CulturalHistorical Psychology. Cambridge: CUP. p. 63-97.

Recebido em: 07/03/2020

Aprovado em: 31/08/2020 